\title{
Degradation of the antibiotic sulfamonomethoxine sodium in aqueous solution by photo-Fenton oxidation
}

\author{
SUN JianHui, FENG JingLan*, SHI ShaoHui, PI YunQing, SONG MengKe \& SHI Yan \\ College of Chemistry and Environmental Sciences, Henan Normal University, Henan Key Laboratory for Environmental Pollution Control, Key \\ Laboratory for Yellow River and Huaihe River Water Environment and Pollution Control, Ministry of Enducation, Xinxiang 453007, China
}

Received December 27, 2010; accepted July 5, 2011

\begin{abstract}
In this study, photo-Fenton oxidation was applied to degradation of sulfamonomethoxine sodium (SMMS) in aqueous solution. The operation parameters of $\mathrm{pH}$, temperature, and concentrations of $\mathrm{H}_{2} \mathrm{O}_{2}, \mathrm{Fe}^{2+}$ and SMMS were investigated. The optimum conditions for the photo-Fenton process were determined as follows: [SMMS] $=4.53 \mathrm{mg} / \mathrm{L}, \mathrm{pH} 4.0,\left[\mathrm{H}_{2} \mathrm{O}_{2}\right]=0.49 \mathrm{mmol} / \mathrm{L},\left[\mathrm{Fe}^{2+}\right]=$ $19.51 \mu \mathrm{mol} / \mathrm{L}$ and $T=25^{\circ} \mathrm{C}$. Under these conditions $98.5 \%$ of the SMMS degraded. The kinetics were also studied, and degradation of SMMS by the photo-Fenton process could be described by first-order kinetics. The apparent activation energy was calculated as $23.95 \mathrm{~kJ} / \mathrm{mol}$. Mineralization of the process was investigated by measuring the chemical oxygen demand (COD), and the COD decreased by $99 \%$ after 120 min. This process could be used as a pretreatment method for wastewater containing sulfamonomethoxine sodium.
\end{abstract}

sulfamonomethoxine sodium, degradation, photo-Fenton

Citation: Sun J H, Feng J L, Shi S H, et al. Degradation of the antibiotic sulfamonomethoxine sodium in aqueous solution by photo-Fenton oxidation. Chin Sci Bull, 2012, 57: 558-564, doi: 10.1007/s11434-011-4887-z

Pharmaceuticals and personal care products (PPCPs) are frequently used in daily life. Recently, they have attracted increasing interest throughout the world because they adversely affect aquatic ecosystems [1-10]. Although their concentrations in the environment are low (ppm or ppb levels), they cause great harm. In fact, most PPCPs and their metabolites are ultimately discharged into wastewater treatment plants (WWTPs), which are typically not designed to remove these specialized organic chemicals. As a result, substantial quantities of these compounds are released into the aquatic environment [11-17].

Antibiotics are a class of PPCPs that are used to prevent or treat bacterial infections. Sulfamonomethoxine sodium (SMMS) is a typical antibiotic that is a persistent sulfa veterinary drug. It is widely used because it has the best antibacterial activity among the sulfa drugs. SMMS is active against Gram-negative and Gram-positive bacteria, and has a strong protozoacide function. However, several authors

*Corresponding author (email: fengj11123@yahoo.com.cn) have reported that only $0-60 \%$ of some sulfa drugs are removed from wastewater by traditional methods $[8,18,19]$. Therefore, alternative technology to remove sulfa drugs from wastewater is required.

In recent years, advanced oxidation processes (AOPs) have been identified as an attractive option for wastewater treatment, particularly in the case of contaminants that are difficult to remove or eliminate by conventional biological or physicochemical technologies [20-23]. AOPs are based on the generation of highly reactive and nonselective oxidant hydroxyl radicals $(\mathrm{OH})$, which can oxidize a broad range of organic pollutants to $\mathrm{CO}_{2}$ and $\mathrm{H}_{2} \mathrm{O}$. Among the most promising AOPs, application of Fenton's reagent is noteworthy because of its high oxidation power, rapid oxidation kinetics, relatively low cost, simplicity of equipment and mild operation conditions [24]. Fenton's reactions include the following main steps (eqs. (1)-(7)):

$$
\begin{gathered}
\mathrm{H}_{2} \mathrm{O}_{2}+\mathrm{Fe}^{2+} \rightarrow \mathrm{Fe}^{3+}+\cdot \mathrm{OH}+\mathrm{OH}^{-} \\
\mathrm{B}+\cdot \mathrm{OH} \rightarrow \mathrm{B}_{\mathrm{OX}}
\end{gathered}
$$




$$
\begin{gathered}
\mathrm{Fe}^{3+}+\mathrm{H}_{2} \mathrm{O}_{2} \rightarrow \mathrm{Fe}^{2+}+\cdot \mathrm{OOH}+\mathrm{H}^{+} \\
\mathrm{Fe}^{3+}+\cdot \mathrm{OOH} \rightarrow \mathrm{Fe}^{2+}+\mathrm{O}_{2}+\mathrm{H}^{+} \\
\cdot \mathrm{OH}+\mathrm{H}_{2} \mathrm{O}_{2} \rightarrow \cdot \mathrm{OOH}+\mathrm{H}_{2} \mathrm{O} \\
\cdot \mathrm{HO}_{2}+\cdot \mathrm{OH} \rightarrow \mathrm{H}_{2} \mathrm{O}+\mathrm{O}_{2} \\
\cdot \mathrm{OH}+\mathrm{Fe}^{2+} \rightarrow \mathrm{Fe}^{3+}+\mathrm{OH}^{-}
\end{gathered}
$$

In the past few years, many studies have shown that degradation of pollutants in water by the Fenton process was greatly enhanced by ultraviolet (UV) irradiation [25-28]. The combination of Fenton's reagent with UV is called the photo-Fenton process. In the photo-Fenton process, the formation of $\mathrm{OH}$ occurs by the following reactions (eqs. (8) and (9)) in addition to those given above [29].

$$
\begin{gathered}
\mathrm{H}_{2} \mathrm{O}_{2}+\mathrm{UV} \rightarrow 2 \cdot \mathrm{OH} \\
\mathrm{Fe}^{3+}+\mathrm{H}_{2} \mathrm{O}_{2}+\mathrm{UV} \rightarrow \mathrm{Fe}^{2+}+\cdot \mathrm{OH}+\mathrm{H}^{+}
\end{gathered}
$$

The addition of UV to the Fenton's process could be useful for degradation of PPCPs because of the direct formation of $\cdot \mathrm{OH}$ radicals. However, many factors will affect the degradation efficiency of organic pollutants in the photo-Fenton system, including $\mathrm{pH}$, temperature, and the concentrations of $\mathrm{H}_{2} \mathrm{O}_{2}, \mathrm{Fe}^{2+}, \mathrm{Cl}^{-}$, dissolved organic matter (DOM) and contaminations [27,30].

The aim of this work was to assess the performance of the photo-Fenton process in the treatment of SMMS wastewater, and to investigate the influence of $\mathrm{pH}$, temperature, concentrations of reagents, reaction time and the kinetics. The mineralization of the photo-Fenton process was evaluated by measuring the chemical oxygen demand (COD). Optimum conditions were established for potential application of the photo-Fenton process to treatment of SMMS wastewater. These results provide a basis for the treatment of SMMS wastewater by the photo-Fenton process.

\section{Experimental}

\subsection{Materials}

SMMS was obtained from Boyahua Science and Technology Co. Ltd. (Beijing, China) (Table 1). Hydrogen peroxide $\left(\mathrm{H}_{2} \mathrm{O}_{2}\right)(30 \%)$, ferrous sulfate $\left(\mathrm{FeSO}_{4} \cdot 7 \mathrm{H}_{2} \mathrm{O}\right)$, mercury sul- fate $\left(\mathrm{HgSO}_{4}\right)$, dipotassium titanium oxide dioxalate $\left(\mathrm{K}_{2} \mathrm{TiO}\right.$ $\left.\left(\mathrm{C}_{2} \mathrm{O}_{4}\right)_{2}\right)$, silver sulfate $\left(\mathrm{Ag}_{2} \mathrm{SO}_{4}\right)$, potassium dichromate $\left(\mathrm{K}_{2} \mathrm{Cr}_{2} \mathrm{O}_{7}\right)$, and ferrous ammonium sulfate $\left(\left(\mathrm{NH}_{4}\right)_{2} \mathrm{Fe}\left(\mathrm{SO}_{4}\right)_{2}\right)$, were all analytical grade. Deionized water was used throughout this study, including to prepare the SMMS solutions.

\subsection{Procedures}

All experiments were carried out in a $200 \mathrm{~mL}$ double glass cylindrical jacket reactor (Figure 1), which allowed cycling of water to maintain the temperature of the reaction system. The temperature $(20-40) \pm 0.5^{\circ} \mathrm{C}$ was adjusted by a thermostat and a magnetic stirrer was used to mix the reaction solutions at $200 \mathrm{r} / \mathrm{min}$. To start each test, $100 \mathrm{~mL}$ of SMMS solution was placed in the double glass cylindrical jacket reactor. The $\mathrm{pH}$ of each reaction solution was adjusted to the desired level using $1.0 \mathrm{~mol} / \mathrm{L}$ sulfuric acid or $1.0 \mathrm{~mol} / \mathrm{L}$ sodium hydroxide. The required amounts of $\mathrm{Fe}^{2+}$ and $\mathrm{H}_{2} \mathrm{O}_{2}$ were then added to the reactor and the solution was stirred magnetically for the reaction time. In the photo-Fenton process, a $12 \mathrm{~W}$ UV lamp (ZF-2, Shanghai AnTing Electron Instrument Factory, China) with an irradiation wavelength of $365 \mathrm{~nm}$ was turned on when the $\mathrm{H}_{2} \mathrm{O}_{2}$ was added. The reaction time was recorded from when the $\mathrm{H}_{2} \mathrm{O}_{2}$ was added to the solution. Samples were periodically removed from the reactor using a pipette. All samples were filtered through $0.45 \mu \mathrm{m}$ filter paper before analysis.

\subsection{Analysis}

The UV spectra of the SMMS aqueous solution was scanned on a Lambda 17 UV-Visible (UV-Vis) spectrophotometer (Lambda 17, Perkin Elmer, USA). No new absorption peaks occurred near the maximum wavelength $(260 \mathrm{~nm})$. Thus, the concentration of SMMS in the reaction solutions was obtained by measuring the absorbance at $\lambda_{\max }(260 \mathrm{~nm})$.

The mineralization of SMMS was measured by the decrease of COD of the reaction solution. COD was measured according to the standard dichromate titration method. To eliminate interference from $\mathrm{H}_{2} \mathrm{O}_{2}$ in COD measurement, the

\begin{tabular}{|c|c|c|c|c|}
\hline Name & Chemical structure & Molecular formula & Molecular weight (g/mol) & $\lambda_{\max }(\mathrm{nm})$ \\
\hline SMMS & & $\mathrm{C}_{11} \mathrm{H}_{11} \mathrm{~N}_{4} \mathrm{NaO}_{3} \mathrm{~S}$ & 302.3 & 260 \\
\hline
\end{tabular}
$\mathrm{H}_{2} \mathrm{O}_{2}$ concentration was determined spectrophotometrically using titanium oxalate [31], and then subtracted from the COD calculation. A blank experiment was conducted simultaneously. The mineralization efficiency of SMMS was estimated from the following equation:

Table 1 Chemical characteristics of SMMS 


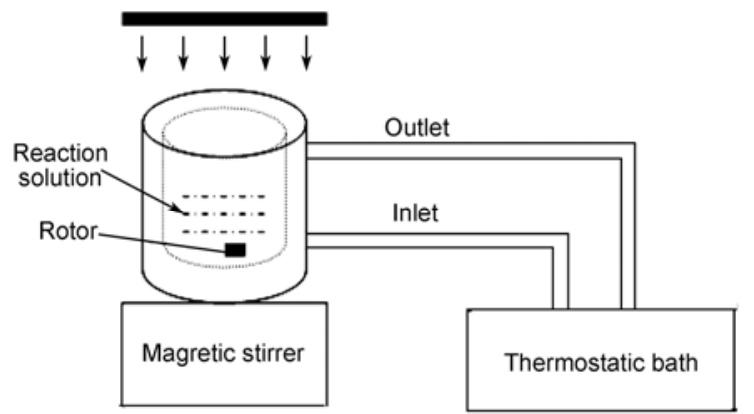

Figure 1 The experimental setup.

Mineralization of $\operatorname{SMMS}(\%)=\left(1-\frac{\mathrm{COD}_{t}}{\mathrm{COD}_{0}}\right) \times 100 \%$,

where $\mathrm{COD}_{0}$ and $\mathrm{COD}_{t}$ are the $\mathrm{COD}$ concentration at the start of reaction, and at time $t(\mathrm{~h})$, respectively.

The $\mathrm{pH}$ of each solution was measured by a pHS-3C digital $\mathrm{pH}$ meter. Before measurement, the $\mathrm{pH}$ meter was cali-

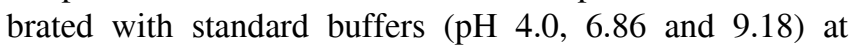
$25^{\circ} \mathrm{C}$.

\section{Results and discussion}

\subsection{Degradation of SMMS wastewater by Fenton and photo-Fenton processes}

The degradation of SMMS in aqueous solution by Fenton and photo-Fenton oxidation processes was studied and the results are shown in Figure 2. Both the Fenton and photo-Fenton process degraded SMMS effectively. However, after $120 \mathrm{~min}$, the degradation efficiency of SMMS in the photo-Fenton process $(98.5 \%)$ was much higher than that in the Fenton process (87.4\%). Formation of more hydroxyl radical in the photo-Fenton process may lead to the relatively high degradation efficiency of SMMS compared to the Fenton process. This can be explained by eqs. (8) and (9). Under UV irradiation, $\mathrm{H}_{2} \mathrm{O}_{2}$ will directly decompose into $\cdot \mathrm{OH}$ in the photo-Fenton process, while $\mathrm{OH}$ formation requires $\mathrm{Fe}^{2+}$ catalysis in the Fenton process. Additionally, $\mathrm{Fe}^{3+}$ in solution could be reduced to $\mathrm{Fe}^{2+}$ and simultaneously form $\mathrm{OH}$ under UV irradiation. Photolysis of SMMS with UV treatment partly accounted for the increase in the degradation efficiency in the photo-Fenton system. Kim et al. [28] reported that more than $90 \%$ of SMMS was degraded when UV irradiation was used alone. However, a considerable UV dose would be needed $\left(230 \mathrm{~mJ} / \mathrm{cm}^{2}\right.$ in $\left.10 \mathrm{~min}\right)$ to degrade SMMS in water to a very low concentration regardless of the UV lamp applied. These results indicated that the UV lamp was of importance for degradation of SMMS even though the UV lamp was of low power (12 W). Relatively high degradation efficiency for the treatment of SMMS wastewater was obtained by the photo-Fenton oxidation process, and this was adopted for subsequent reactions.

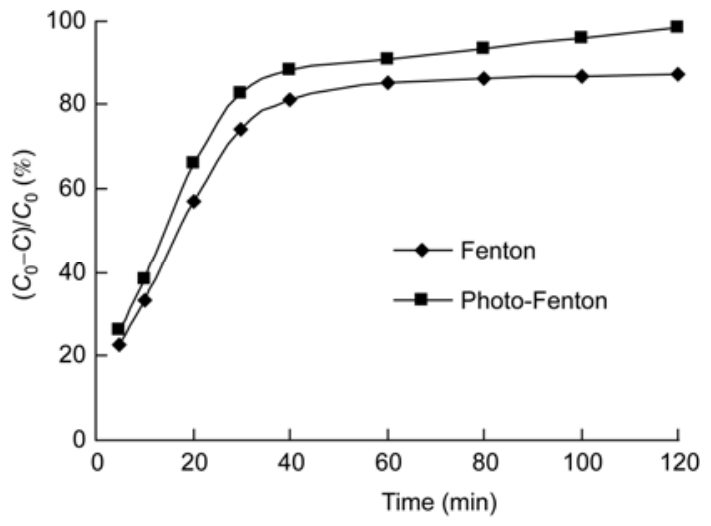

Figure 2 Degradation of SMMS in wastewater by Fenton $(\bullet)$ and photo-Fenton (घ) processes. Experimental conditions: [SMMS] $=4.53 \mathrm{mg} / \mathrm{L}$, $\left[\mathrm{H}_{2} \mathrm{O}_{2}\right]=0.49 \mathrm{mmol} / \mathrm{L},\left[\mathrm{Fe}^{2+}\right]=19.51 \mu \mathrm{mol} / \mathrm{L}, \mathrm{pH} 4.0$ and $T=25^{\circ} \mathrm{C}$.

\subsection{Optimization of reaction parameters}

(1) Effect of $\mathrm{pH}$. The effect of $\mathrm{pH}$ on the degradation of SMMS in the photo-Fenton process was evaluated by running the reaction at various $\mathrm{pH}$ values while holding the other operating parameters constant. The change in degradation efficiency with the change in $\mathrm{pH}$ is presented in Figure 3. The optimum $\mathrm{pH}$ for degradation of SMMS in photoFenton process was 4.0 , and increasing or decreasing the $\mathrm{pH}$ decreased the degradation efficiency. At low $\mathrm{pH}$, formation of the oxonium ion $\left(\mathrm{H}_{3} \mathrm{O}_{2}^{+}\right)$enhanced the stability of $\mathrm{H}_{2} \mathrm{O}_{2}$ and restricted the generation of $\cdot \mathrm{OH}$ [32]. In addition, $\mathrm{H}^{+}$ could act as an $\mathrm{OH}$ scavenger. At high $\mathrm{pH}$, ferric oxyhydroxides would precipitate and stop the reaction of $\mathrm{Fe}^{3+}$ with $\mathrm{H}_{2} \mathrm{O}_{2}$ to regenerate $\mathrm{Fe}^{2+}$, which would reduce the amount of $\cdot \mathrm{OH}[20,29]$. Therefore, $\mathrm{pH} 4.0$ was optimum for the photo-Fenton process, and resulted in a maximum degradation of SMMS of $98.5 \%$.

(2) Effect of $\mathrm{H}_{2} \mathrm{O}_{2}$ concentration. $\mathrm{H}_{2} \mathrm{O}_{2}$, which was the source of $\cdot \mathrm{OH}$, played a very important role in the photo-

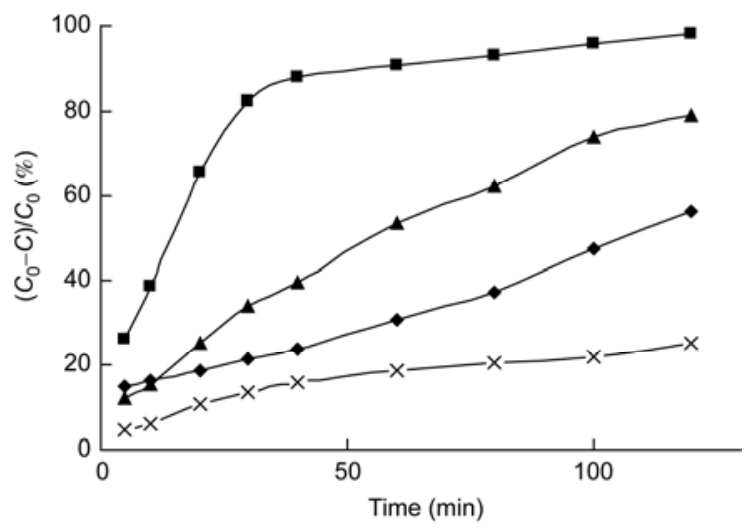

Figure 3 Effect of the $\mathrm{pH}$ on the degradation of SMMS in wastewater by the photo-Fenton process. Experimental conditions: [SMMS] $=4.53 \mathrm{mg} / \mathrm{L}$; $\left[\mathrm{H}_{2} \mathrm{O}_{2}\right]=0.49 \mathrm{mmol} / \mathrm{L} ;\left[\mathrm{Fe}^{2+}\right]=19.51 \mu \mathrm{mol} / \mathrm{L} ; \mathrm{pH} 3.0(\diamond), \mathrm{pH} 4.0(\mathbf{\bullet}), \mathrm{pH}$ $5.0(\mathbf{\Delta}), \mathrm{pH} 6.0(\times)$; and $T=25^{\circ} \mathrm{C}$. 
Fenton process. The effect of $\mathrm{H}_{2} \mathrm{O}_{2}$ concentration on degradation of SMMS was examined by varying the concentration of $\mathrm{H}_{2} \mathrm{O}_{2}$ from $0.098-1.92 \mathrm{mmol} / \mathrm{L}$ (Figure 4). Increasing $\left[\mathrm{H}_{2} \mathrm{O}_{2}\right]$ from 0.29 to $0.49 \mathrm{mmol} / \mathrm{L}$ generally had a positive effect on the degradation of SMMS because the high $\mathrm{H}_{2} \mathrm{O}_{2}$ concentration generated more $\cdot \mathrm{OH}$. However, this was not always the case. For example, degradation of SMMS declined from $98.5 \%$ to $92.2 \%$ when the concentration of $\mathrm{H}_{2} \mathrm{O}_{2}$ was increased from 0.49 to $1.92 \mathrm{mmol} / \mathrm{L}$ in the photo-Fenton process. This phenomenon has been widely reported by many researchers [20,22,27,29]. This could be explained by a critical concentration of $\mathrm{H}_{2} \mathrm{O}_{2}$ in the Fenton oxidation process. As the concentration of $\mathrm{H}_{2} \mathrm{O}_{2}$ increased beyond the critical value, it would become a scavenger of $\cdot \mathrm{OH}$ (eqs. (5) and (6)). The optimum concentration of $\left[\mathrm{H}_{2} \mathrm{O}_{2}\right]$ was $0.49 \mathrm{mmol} / \mathrm{L}$.

(3) Effect of $\mathrm{Fe}^{2+}$ concentration. As a catalyst in the Fenton's reagent, $\mathrm{Fe}^{2+}$ initiates decomposition of $\mathrm{H}_{2} \mathrm{O}_{2}$ to generate $\cdot \mathrm{OH}$. Therefore, the initial concentration of $\mathrm{Fe}^{2+}$ is an important parameter in the photo-Fenton process. The effect of $\left[\mathrm{Fe}^{2+}\right]$ on the degradation of SMMS in photo-Fenton processes was studied. The results (Figure 5) indicated that the extent of SMMS degradation was highly dependent on the $\left[\mathrm{Fe}^{2+}\right]$. Degradation of SMMS was low at low $\left[\mathrm{Fe}^{2+}\right]$, and increased when the $\left[\mathrm{Fe}^{2+}\right]$ was increased. The high degradation efficiency at high $\left[\mathrm{Fe}^{2+}\right]$ could be mainly attributed to increased production of $\mathrm{OH}$ with more $\mathrm{Fe}^{2+}$ in the photo-Fenton reaction.

It was important to detect the optimum molar ratio of $\left[\mathrm{H}_{2} \mathrm{O}_{2}\right] /\left[\mathrm{Fe}^{2+}\right]$ because this ratio can directly affect the production of $\mathrm{OH}$ in the Fenton reaction. The effect of high $\left[\mathrm{Fe}^{2+}\right](28.99 \mu \mathrm{mol} / \mathrm{L})$ on the photo-Fenton process is plotted in Figure 5. High $\left[\mathrm{Fe}^{2+}\right]$ was not good for the degradation efficiency, and only $93.1 \%$ of the SMMS degraded in photo-Fenton process at this $\left[\mathrm{Fe}^{2+}\right]$. There is currently no agreement in the literature on the optimum molar ratio of $\left[\mathrm{H}_{2} \mathrm{O}_{2}\right] /\left[\mathrm{Fe}^{2+}\right]$ for the treatment of various wastewaters by this oxidation process $[21,27]$. In the present study, experi-

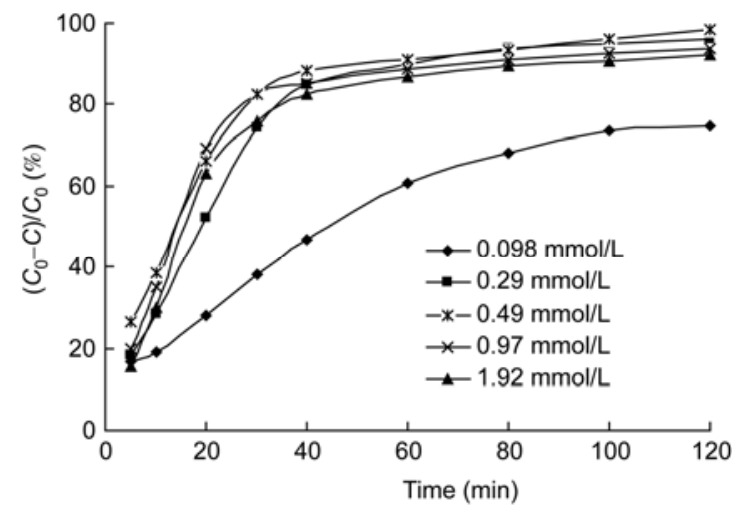

Figure 4 Effect of the $\left[\mathrm{H}_{2} \mathrm{O}_{2}\right]$ on the degradation of SMMS in wastewater by the photo-Fenton process. Experimental conditions: [SMMS] $=4.53 \mathrm{mg} / \mathrm{L}$, $\left[\mathrm{Fe}^{2+}\right]=19.51 \mu \mathrm{mol} / \mathrm{L}, \mathrm{pH} 4.0$, and $T=25^{\circ} \mathrm{C}$.

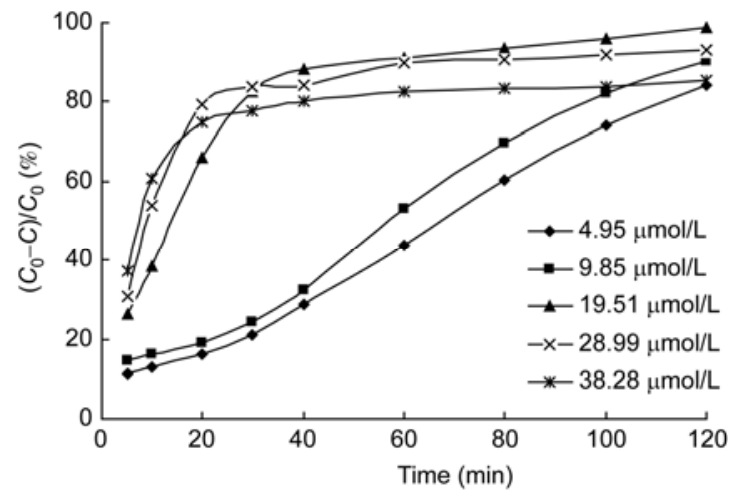

Figure 5 Effect of the $\left[\mathrm{Fe}^{2+}\right]$ on the degradation of SMMS in wastewater by the photo-Fenton process. Experimental conditions: [SMMS] $=4.53 \mathrm{mg} / \mathrm{L}$, $\left[\mathrm{H}_{2} \mathrm{O}_{2}\right]=0.49 \mathrm{mmol} / \mathrm{L}, \mathrm{pH} 4.0$ and $T=25^{\circ} \mathrm{C}$.

ments indicated 25:1 was a suitable $\left[\mathrm{H}_{2} \mathrm{O}_{2}\right] /\left[\mathrm{Fe}^{2+}\right]$ molar ratio for degradation of SMMS, and the optimum $\left[\mathrm{Fe}^{2+}\right]$ was $19.51 \mu \mathrm{mol} / \mathrm{L}$.

(4) Effect of SMMS concentration. The initial [SMMS] was another important factor that could affect the oxidation process. Degradation of different concentrations of SMMS was studied and the results are shown in Figure 6. The degradation of SMMS decreased as its initial concentration increased in the photo-Fenton process. This can be explained by generation of a relatively low concentration of $\cdot \mathrm{OH}$ because the concentrations of $\mathrm{Fe}^{2+}$ and $\mathrm{H}_{2} \mathrm{O}_{2}$ were not increased at the same time as the concentration of SMMS. In addition, in the photo-Fenton process, high concentrations of SMMS would hinder entry of the generated photons to the solutions and lower $\cdot \mathrm{OH}$ concentration [29]. However, after a reaction time of $120 \mathrm{~min}$, no big degradation differences were observed among different concentrations of SMMS in the photo-Fenton process (all between $96.6 \%-$ $98.6 \%)$.

(5) Effect of temperature. Figure 7 shows the extent of

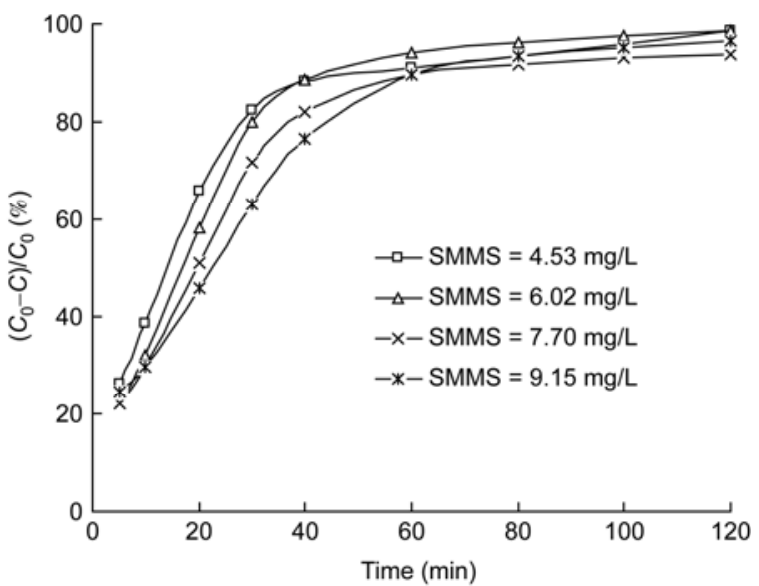

Figure 6 Effect of the [SMMS] on the degradation of SMMS in wastewater by the photo-Fenton process. Experimental conditions: $\left[\mathrm{H}_{2} \mathrm{O}_{2}\right]=$ $0.49 \mathrm{mmol} / \mathrm{L},\left[\mathrm{Fe}^{2+}\right]=19.51 \mu \mathrm{mol} / \mathrm{L}, \mathrm{pH} 4.0$ and $T=25^{\circ} \mathrm{C}$. 


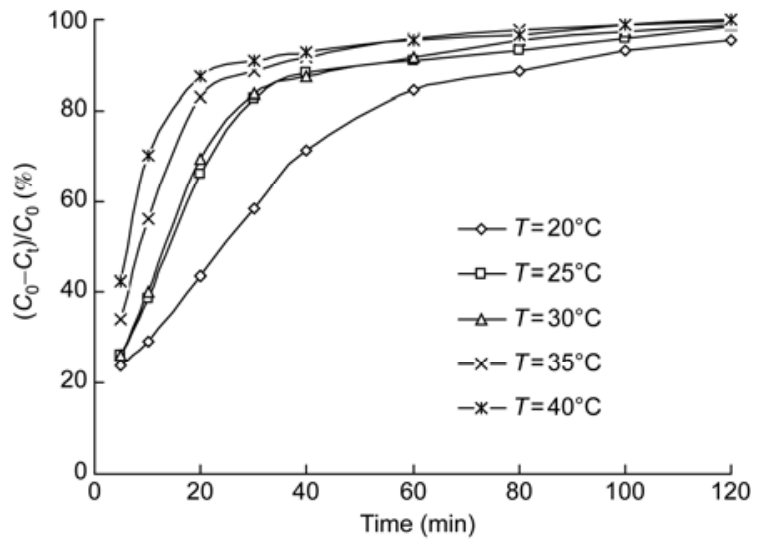

Figure 7 Effect of the temperature on the degradation of SMMS in wastewater by the photo-Fenton process. Experimental conditions: [SMMS]= $4.53 \mathrm{mg} / \mathrm{L},\left[\mathrm{H}_{2} \mathrm{O}_{2}\right]=0.49 \mathrm{mmol} / \mathrm{L},\left[\mathrm{Fe}^{2+}\right]=19.51 \mu \mathrm{mol} / \mathrm{L}$, and $\mathrm{pH} 4.0$.

degradation of SMMS by the photo-Fenton process at different temperatures. In the photo-Fenton process, degradation of SMMS increased obviously with the increase of temperature in the first $30 \mathrm{~min}$. However, after $60 \mathrm{~min}$, degradation of SMMS barely changed. These results could arise from increased generation of $\cdot \mathrm{OH}$ when the temperature was increased, which would enhance the degradation of SMMS. However, $\mathrm{H}_{2} \mathrm{O}_{2}$ would decompose at high temperature. In the photo-Fenton process, $>96.3 \%$ of SMMS degraded at all tested temperatures under the optimum experimental conditions. This reached $100 \%$ after $140 \mathrm{~min}$ in the
photo-Fenton process when temperature was $40^{\circ} \mathrm{C}$. In summary, the temperature had a positive effect on the degradation of SMMS in the photo-Fenton process.

\subsection{Kinetic study}

The AOPs can be represented by the following ${ }^{n}$ th-order reaction kinetics:

$$
\frac{\mathrm{d} C}{\mathrm{~d} t}=-k C^{n}
$$

where $C$ is the concentration of SMMS, $n$ is the order of the reaction, $k$ is the reaction rate constant, and $t$ is the time. For zero-, first- and second-order reactions (eqs. (12), (13), and (14), respectively), the kinetic expression can be presented as follows:

$$
\begin{gathered}
C_{t}=C_{0}-k_{0} t, \\
\ln \left(\frac{C_{0}}{C_{\mathrm{t}}}\right)=k_{1} t, \\
\frac{1}{C_{\mathrm{t}}}=\frac{1}{C_{0}}+k_{2} t .
\end{gathered}
$$

Regression analysis based on the zero-, first- and second-order reaction kinetics for the degradation of SMMS in the photo-Fenton processes was studied and the results are shown in Figure 8(a), (b), and (c). The correlation
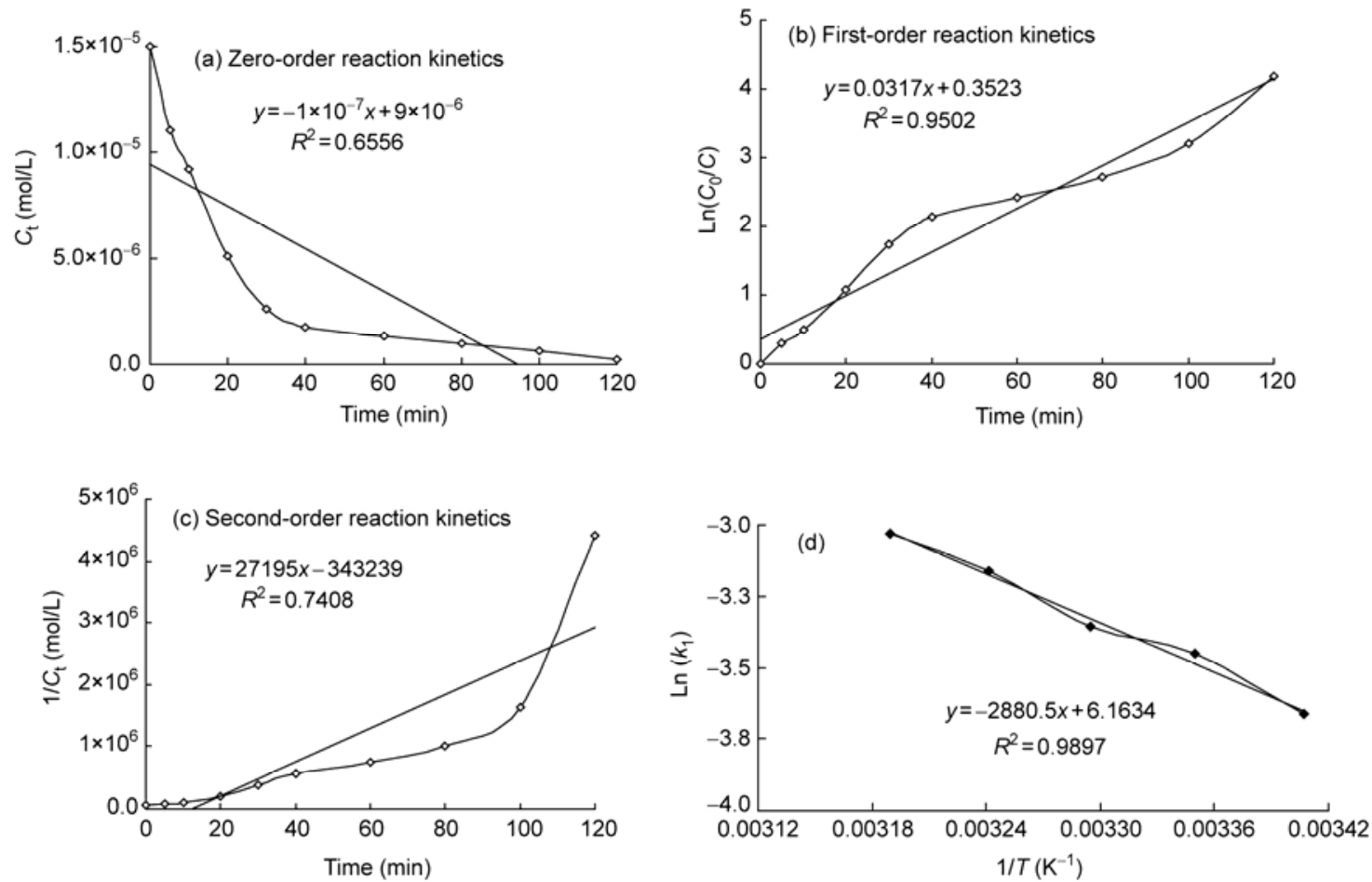

Figure 8 The $n^{\text {th }}$-order kinetics of the degradation of SMMS in wastewater by the photo-Fenton process. Experimental conditions: [SMMS]= 4.53 mg/L, $\left[\mathrm{H}_{2} \mathrm{O}_{2}\right]=0.49 \mathrm{mmol} / \mathrm{L},\left[\mathrm{Fe}^{2+}\right]=19.51 \mu \mathrm{mol} / \mathrm{L}, \mathrm{pH} 4.0$ and $T=25^{\circ} \mathrm{C}$. 
between $\ln \left(C_{0} / C\right)$ and reaction time $t$ was linear $\left(R^{2}=\right.$ 0.9502), which is typical of a pseudo-first-order reaction. Therefore, degradation of SMMS in the photo-Fenton process follows pseudo-first-order kinetics. From Figure 8, we could obtain the rate constant $(0.0317 / \mathrm{min})$ for degradation of SMMS in the photo-Fenton processes.

In the photo-Fenton process, we also validated the rate constant $\left(k_{1}\right)$ by the Arrhenius equation (eq. (15)):

$$
\ln k_{1}=\ln A-\frac{E a}{R T},
$$

where $A$ is the pre-exponential factor, $E$ is the apparent activation energy $(\mathrm{J} / \mathrm{mol}), R$ is the ideal gas constant $(8.314$ $\mathrm{J} / \mathrm{mol} \mathrm{K})$, and $T$ is the absolute temperature $(\mathrm{K})$. The plot of $\ln k_{1}$ versus $1 / T$ is shown in Figure $8(\mathrm{~d})$. There was a good linear relationship between $\ln k_{1}$ and $1 / T\left(R^{2}=0.9897\right)$. The apparent activation energy $E=23.95 \mathrm{~kJ} / \mathrm{mol}$ was obtained from the slope of the plot, and the pre-exponential factor $A=170.80 / \mathrm{min}$ was obtained from the $y$-intercept. Typical thermal reactions usually have reaction activation energies between 60 and $250 \mathrm{~kJ} / \mathrm{mol}$ [23]. The apparent activation energy in this study implied that the degradation of SMMS in aqueous solution by the photo-Fenton oxidation process required much lower activation energy and could be easily achieved.

\subsection{Mineralization study}

During the SMMS degradation, some aromatic intermediates will be form. These new compounds may be more difficult to degrade and more toxic than the parent compounds. The COD is related to the total concentration of organic compounds in the solution. Therefore, the reduction in COD can reflect the degree of mineralization. To quantify the degree of mineralization of SMMS in the photo-Fenton processes, COD was measured and the results are shown in Figure 9. The COD decreased by $99 \%$ after $120 \mathrm{~min}$ of

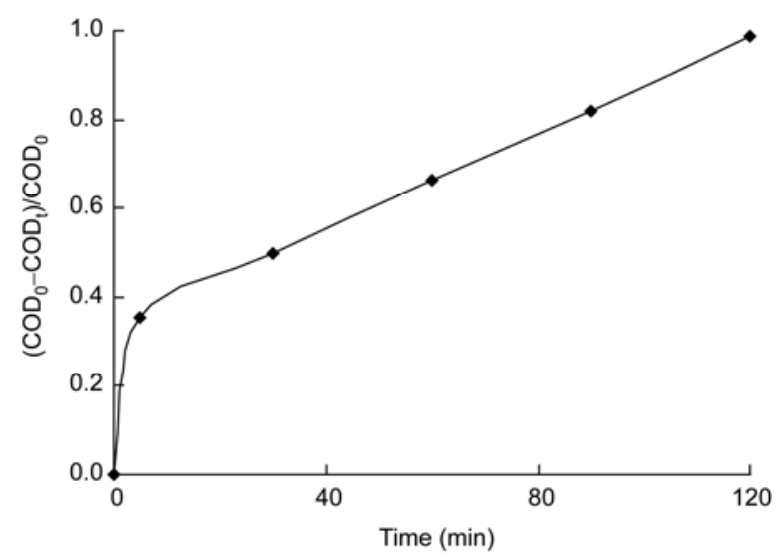

Figure 9 COD reduction during the degradition of SMMS in wastewater by the photo-Fenton process. Experimental conditions: [SMMS] $=4.53 \mathrm{mg} / \mathrm{L}$, $\left[\mathrm{H}_{2} \mathrm{O}_{2}\right]=0.49 \mathrm{mmol} / \mathrm{L},\left[\mathrm{Fe}^{2+}\right]=19.51 \mu \mathrm{mol} / \mathrm{L}, \mathrm{pH} 4.0$ and $T=25^{\circ} \mathrm{C}$. reaction, which suggests that nearly all of intermediates were mineralized at this stage. After this time it is likely the wastewater will not be toxic, with respect to its SMMS content, to the environment. It is worth noting that in the first 5 min degradation of SMMS was much faster than at later stages, and the COD decreased by $36 \%$ in this time. This indicates that most of the compounds begin to decompose in the first $5 \mathrm{~min}$. These results show that the photo-Fenton process is promising for treatment of this kind of wastewater, even though the UV lamp is low power $(12 \mathrm{~W})$.

\section{Conclusions}

In this paper, the degradation of SMMS by the photo-Fenton process was investigated. The optimum degradation conditions for SMMS in the photo-Fenton process were determined as follows: [SMMS] $=4.53 \mathrm{mg} / \mathrm{L}, \mathrm{pH} 4.0,\left[\mathrm{H}_{2} \mathrm{O}_{2}\right]=$ $0.49 \mathrm{mmol} / \mathrm{L},\left[\mathrm{Fe}^{2+}\right]=19.51 \mu \mathrm{mol} / \mathrm{L}$ and $T=25^{\circ} \mathrm{C}$. Under the optimum conditions, $98.5 \%$ of the SMMS was degraded after $120 \mathrm{~min}$. Degradation of SMMS in photo-Fenton process was described by first-order kinetics, and the apparent activation energy was determined to be $23.95 \mathrm{~kJ} / \mathrm{mol}$. Mineralization of the process was studied by measuring the chemical oxygen demand (COD), and the COD decreased by $99 \%$ after $120 \mathrm{~min}$, which suggests that nearly all of intermediates are mineralized at this stage of the reaction. These results provide a basis for the treatment of wastewater containing SMMS by AOPs.

This work was supported by the Key Scientific and Technological Program of Henan Province (0522030700, 102102310303 and 0611020900). Special thanks go to Liu Junjun from Henan Normal University, for his contribution to this paper.

1 Halling-Sorensen B, Nielsen S N, Lanzky P F, et al. Occurrence, fate and effects of pharmaceutical substances in the environment-A review. Chemosphere, 1998, 36: 357-394

2 Daugthon C G, Ternes T A. Pharmaceuticals and personal care products in the environment: Agents of subtle change? Environ Health Perspect, 1999, 107(Suppl 6): 907-938

3 Latch D E, Stender B L, Packer J L, et al. Photochemical fate of pharmaceuticals in the environment: Cimetidine and ranitidine. Environ Sci Technol, 2003, 37: 3342-3350

4 Boreen A L, Arnold W A, McNeill K. Photochemical fate of sulfa drugs in the aquatic environment: Sulfa drugs containing five-membered heterocyclic groups. Environ Sci Technol, 2004, 38: 39333940

5 Richardson B J, Lam P K S, Martin M. Emerging chemicals of concern: Pharmaceuticals and personal care products (PPCPs) in Asia, with particular reference to southern China. Mar Pollut Bull, 2005, 50: 913-920

6 Matamoros V, Bayona J M. Elimination of pharmaceuticals and personal care products in subsurface flow constructed wetlands. Environ Sci Technol, 2006, 40: 5811-5816

7 Edhlund B L, Arnold W A, McNeill K. Aquatic photochemistry of nitrofuran antibiotics. Environ Sci Technol, 2006, 40: 5422-5427

$8 \mathrm{Xu} \mathrm{W} \mathrm{H,} \mathrm{Zhang} \mathrm{G,} \mathrm{Li} \mathrm{X} \mathrm{D,} \mathrm{et} \mathrm{al.} \mathrm{Occurrence} \mathrm{and} \mathrm{elimination} \mathrm{of} \mathrm{anti-}$ biotics at four sewage treatment plants in the Pearl River Delta (PRD), 
South China. Water Res, 2007, 41: 4526-4534

9 Matamoros V, Arias C, Brix H, et al. Removal of pharmaceuticals and personal care products (PPCPs) from urban wastewater in a pilot vertical flow constructed wetland and a sand filter. Environ Sci Technol, 2007, 41: 8171-8177

10 Miege C, Choubert J M, Ribeiro L, et al. Fate of pharmaceuticals and personal care products in wastewater treatment plants-Conception of a database and first results. Environ Pollut, 2009, 157: 1721-1726

11 Heberer T. Occurrence, fate, and removal of pharmaceutical residues in the aquatic environment: A review of recent research data. Toxicol Lett, 2002, 131: 5-17

12 Balmer M E, Buser H R, Müller M D, et al. Occurrence of some organic UV filters in wastewater, in surface waters, and in fish from Swiss lakes. Environ Sci Technol, 2005, 39: 953-962

13 Lishman L, Smyth S A, Sarafin K, et al. Occurrence and reductions of pharmaceuticals and personal care products and estrogens by municipal wastewater treatment. Sci Total Environ, 2006, 367: 544-558

14 Xu W H, Zhang G, Zou S C, et al. Determination of selected antibiotics in the Victoria Harbour and the Pearl River, South China using high-performance liquid chromatography-electrospray ionization tandem mass spectrometry. Environ Pollut, 2007, 145: 672-679

15 Lee J, Lee B C, Ra J S, et al. Comparison of the removal efficiency of endocrine disrupting compounds in pilot scale sewage treatment processes. Chemosphere, 2008, 71: 1582-1592

16 Zhang Y J, GeiBen S U, Gal C. Carbamazepine and diclofenac: Removal in wastewater treatment plants and occurrence in water bodies. Chemosphere, 2008, 73: 1151-1161

17 Zhao J L, Ying G G, Wang L, et al. Determination of phenolic endocrine disrupting chemicals and acidic pharmaceuticals in surface water of the Pearl Rivers in South China by gas chromatography-negative chemical ionization-mass spectrometry. Sci Total Environ, 2009, 407: 962-974

18 Carballa M, Omil F, Lema L M, et al. Behavior of pharmaceuticals, cosmetics and hormones in a sewage treatment plant. Water Res, 2004, 38: 2918-2926

19 Peng X Z, Wang Z D, Kuang W X, et al. A preliminary study on the occurrence and behavior of sulfonamides, ofloxacin and chloramphenicol antimicrobials in wastewaters of two sewage treatment plants in Guangzhou, China. Sci Total Environ, 2006, 371: 314-322

20 Benitez F J, Acero J L, Real F J, et al. The role of hydroxyl radicals for the decomposition of p-hydroxyl phenyl acetic acid in aqueous solutions. Water Res, 2001, 35: 1338-1343

21 Malik P K, Saha S K. Oxidation of direct dyes with hydrogen peroxide using ferrous ion as catalyst. Sep Purif Technol, 2003, 31: 241250

22 Anotai J, Lu M C, Chewpreecha P. Kinetics of aniline degradation by Fenton and electro-Fenton processes. Water Res, 2006, 40: 18411847

23 Chen J X, Zhu L Z. Heterogeneous UV-Fenton catalytic degradation of dyestuff in water with hydroxyl-Fe pillared bentonite. Catal Today, 2007, 126: 463-470

24 Zazo J A, Casas J A, Mohedano A F, et al. Chemical pathway and kinetics of phenol oxidation by Fenton's reagent. Environ Sci Technol, 2005, 39: 9295-9302

25 Perez M, Torrades F, Domenech X, et al. Fenton and photo-Fenton oxidation of textile effluents. Water Res, 2002, 36: 2703-2710

26 Zhao Y P, Hu J Y, Jin W. Transformation of oxidation products and reduction of estrogenic activity of $17 \beta$-estradiol by a heterogeneous photo-Fenton reaction. Environ Sci Technol, 2008, 42: 5277-5284

27 Sun S P, Li C J, Sun J H, et al. Decolorization of an azo dye Orange $\mathrm{G}$ in aqueous solution by Fenton oxidation process: Effect of system parameters and kinetic study. J Hazard Mater, 2009, 161: 1052-1057

28 Kim I, Tanaka H. Photodegradation characteristics of PPCPs in water with UV treatment. Environ Int, 2009, 35: 793-802

29 Lucas M S, Peres J A. Decolorization of the azo dye Reactive Black 5 by Fenton and photo-Fenton oxidation. Dyes Pigm, 2006, 71: 236244

30 Ge L K, Chen J W, Qiao X L, et al. Light-source-dependent effects of main water constituents on photodegradation of phenicol antibiotics: Mechanism and kinetics. Environ Sci Technol, 2009, 43: 3101-3107

31 Sun J H, Li X Y, Feng J L, et al. Oxone/ $\mathrm{Co}^{2+}$ oxidation as an advanced oxidation process: Comparison with traditional Fenton oxidation for treatment of landfill leachate. Water Res, 2009, 43: 4363-4369

32 Modirshahla N, Behnajady M A, Ghanbary F. Decolorization and mineralization of C.I. Acid Yellow 23 by Fenton and photo-Fenton processes. Dyes Pigm, 2007, 73: 305-310

Open Access This article is distributed under the terms of the Creative Commons Attribution License which permits any use, distribution, and reproduction in any medium, provided the original author(s) and source are credited. 